\title{
IYÁS E ABEBÉS: EXISTÊNCIAS, RESISTÊNCIAS E LUTAS MATRIARCAIS AFRODIASPÓRICAS
}

\author{
Mauricio dos Santos ${ }^{1}$ \\ Anaxsuell Fernando da Silva ${ }^{2}$ \\ DOI 10.26512/revistacalundu.v4i2.34579
}

\begin{abstract}
Resumo
Com a Diáspora Negra, aportaram no Brasil as Iyás - mães e Iyabás, que são as divindades matrigestoras afro-brasileiras, vindas do outro lado do Oceano Atlântico. Assim, neste artigo se propõe discutir algumas ideias a respeito de como a divindade afro-brasileira Oxum e o seu espelho de mão, o abebé, são efetivamente belicosos; buscamos também evidenciar alguns elementos das vidas de Makota Valdina, Maria Neném, Doné Runhó, Tia Ciata, Mãe Aninha, Chica Xavier, Mãe Stella de Oxóssi, Mãe Menininha, Olga do Alaketu, Mãe Beata de Iemanjá, Mãe Gilda de Ogun e Giselle Omindarewá, aqui nomeadas como Iyás: Mães de Santo, Matrigeradoras e Matrigestoras afro-brasileiras. A partir de uma pesquisa bibliográfica, identificamos que as lutas antirracistas e feministas são comuns nas vidas dessas Iyás, pois verificamos que em diferentes períodos e em diferentes terreiros essas lutas se repetiram de distintas formas, e compreendemos que as lutas contra o racismo e machismo são constitutivas e/ou uma característica das Iyás afro-brasileiras. Concebemos Oxum como insígnia das Iyás e Iyábás e, entretanto, consideramos que ainda as mulheres de terreiro permanecem invisibilizadas.
\end{abstract}

Palavras-chave: Mães de Santo. Mulheres de Terreiro. Oxum. Abebé. Espelho.

\section{IYÁS Y ABEBÉS: EXISTENCIAS, RESISTENCIAS Y LUCHA MATRARAL AFRODIASPÓRICAS}

\section{Resumen}

Con la diáspora negra, Iyás, que son las madres y Iyabás, las deidades madres afrobrasileñas venidas desde África, al otro lado del Océano Atlántico, llegaron en Brasil. En este artículo se propone discutir algunas ideas sobre cómo la deidad afrobrasileña Oxum y su espejo de mano, el abebé, son efectivamente belicosos; también desejamos enfatizar algunos elementos de la vida de Makota Valdina, Maria Neném, Doné Runhó, Tia Ciata, Madre Aninha, Chica Xavier, Mãe Stella de Oxóssi, Mãe Menininha, Olga do Alaketu, Mãe Beata de Iemanjá, Mãe Gilda de Ogun y Giselle Omindarewá, aquí nominadas como Iyá/Iyás, Mães de Santo, matrigeneradoras e matrigestoras afrobrasileñas. A partir de una investigación bibliográfica, identificamos que las luchas antirracistas y feministas son comunes en la vida de estas Iyás: verificamos que en diferentes períodos y en terreiros estas luchas se repitieron de diferentes maneras, y entendemos que las luchas contra el racismo y el machismo son constitutivas y/o una característica de las Iyás afrobrasileñas. Concebimos Oxum como una insignia de las

\footnotetext{
${ }^{1}$ Universidade Federal da Integração Latino-Americana.

${ }^{2}$ Universidade Federal da Integração Latino-Americana.
} 
Iyás e Iyábás y, sin embargos, consideramos que todavía aun les faltan mucha visibilidad.

Palabras clave: Madres de Santo. Mujeres de Terreiro. Oxum. Abebé. Espejo.

\author{
Eu agora vou cantar para todas as moças, \\ Eu agora vou bater para todas as moças, \\ Eu agora vou dançar para todas as moças, \\ Para todas Ayabás, para todas elas. \\ (Gilberto Gil, "As Ayabás”)
}

Não é nenhuma novidade que o processo de colonização da América Latina compreendia a ocupação/exploração dos territórios e a sujeição tanto dos povos originários que habitavam a região, quanto dos povos que foram trazidos de longe para atuar como força de trabalho para estas regiões, neste último caso majoritariamente os africanos escravizados. Este marco histórico introduziu a experiência da diáspora nos lugares nos quais estas pessoas foram inseridas.

Hoje, no âmbito das Antropologias contemporâneas, não entendemos a diáspora apenas em seu sentido estrito e literal. Isto é, como mero deslocamento físico, em sentido geográfico. Tampouco consideramos somente como uma metáfora para deslocamentos e/ou desterritorializações - o que significou uma ampliação da própria noção de afastamento geográfico. Nos últimos anos, a noção de diáspora passou também a caracterizar um tipo de consciência, de experiência, de produção cultural que põe em xeque modelos fixos de identidade cultural (HALL, 1996).

A superação da compreensão do território como algo reduzível a um substrato fixo, localizável em uma porção qualquer da superfície terrestre, implicou a admissão de um enquadramento do vínculo entre sujeito e sua territorialidade mais subjetivo, mais complexo, simbólico. Tratou-se de concebê-la como um espaço no qual o sujeito inaugura um laço afetivo, constrói sua história e efetiva suas relações e artefatos sociais. Neste sentido, a diáspora pressupõe uma experiência de extraterritorialidade e, portanto, expressa a ideia de uma vida fora do território "terra mãe".

No contexto latino-americano e caribenho, tomamos a diáspora africana como perspectiva para pensar o movimento cultural e religioso de pessoas afrodescendentes, para compreender o fluxo e a dinâmica das crenças e saberes ancestrais que atravessaram o grande atlântico (HALL, 1996), que se constituíram como espaços de memória ou de acolhimento subjetivo e arregimentaram experiências e práticas religiosas em diferentes espaços do nosso continente. 
Assim, movidos pelo cântico de Gilberto Gil, trabalharemos neste artigo como a cosmologia em torno da Iyábá Oxum e seu Abebé, as quais tiveram suas representações distorcidas pela colonialidade do saber/poder.

Colonialidade foi um conceito que foi introduzido pelo sociólogo peruano Anibal Quijano, no início dos anos 1990 e foi reelaborado por outros autores e autoras entre os quais destacamos, neste momento, Walter Mignolo (2003) e suas reflexões no conhecido trabalho Histórias Locais/ Projetos Globais - Colonialidade, Saberes Subalternos. Enquanto colonialismo se refere ao processo e aos aparatos de domínio político e militar que se desenvolvem para garantir a exploração do trabalho e as riquezas das colônias em benefício do colonizador (GROSFOGUEL, 2008); a noção de "colonialidade" se configura como um fenômeno histórico muito mais complexo e se estende até nosso presente, referindo-se a um padrão de poder que opera por meio da naturalização de hierarquias territoriais, raciais, culturais e epistêmicas, possibilitando a reprodução de relações de dominação. Dito de outro modo, nesta compreensão, o colonialismo não acabou com as guerras da independência, mas continuou o processo de dominação na América Latina de diversas maneiras até os dias atuais (QUIJANO, 1997).

É exatamente por isso que é fundamental trazer para o debate acadêmico alguns elementos biográficos das vidas de Iyás de comunidades religiosas afro-brasileiras, pois acreditamos que essa temática pode, em alguma maneira, mesmo que minimamente, contribuir aos/as leitores/as interessados/as em discutir que Oxum não pode ser referenciada e/ou interpretada pela colonialidade do saber/poder (QUIJANO, 1997; OYĚWÙMÍ, 2017) ou colonialidade da religião (SILVA; PROCÓPIO, 2019) e que as Iyás são exemplos de lutas pelas causas antirracistas e anti-machistas. Considerando que mães de santo e/ou mulheres de terreiro possuem "sabedorias vindas da África e cruzadas nas travessias do oceano, [...] sabedorias essas que cotidianamente insistem em dobrar a morte pela via do não esquecimento" (SIMAS; RUFINO, 2019, p.84).

Este debate que apresentamos aqui é construído considerando-se essencialmente materiais escritos e alguns audiovisuais a propósito da crítica à colonialidade (QUIJANO, 1997); as potências de Iyás e da Iyábá Oxum (OYĚWÙMÍ, 2017; FLOR DO NASCIMENTO, 2019; RIBEIRO, 2020; AKOTIRENE, 2019), e suas narrativas mitológicas (SIMAS; RUFINO, 2019; PRANDI, 2020). O objetivo desse texto é mostrar como Oxum e seu Abebé são belicosos e não-eurocêntricos, e exemplificar com notas biográficas de Iyás significativas para as religiões afro-brasileiras, por suas 
matripotências e matrigestões (RIBEIRO, 2020). A ligação entre Iyás, aqui traduzidas como Mães, e de Iyábás, traduzidas como as divindades afro-brasileiras mães, é a própria divindade Oxum, como patrona das mães de santo e das mulheres de terreiro (OYĚWÙMÍ, 2017).

\section{Iyás e Abebés}

Oxum tem sido apresentada pela colonialidade como feminilidade ocidentalizada, e retumbantemente narcisística. Lembremo-nos de que Narciso - ou $O$ Auto Admirador - foi um herói na mitologia grega, considerado muito bonito e que atraía olhares de todos/as, e aqueles/as que foram menosprezados/as por ele pediram aos/as deuses/as gregos/as para vingá-los/as. Assim, Némesis-Afrodite condenou Narciso a apaixonar-se pelo seu próprio reflexo na lagoa de Eco, essa que era uma ninfa que havia se apaixonado pelo rapaz. Obcecado com sua boniteza, Narciso mergulhou na lagoa de Eco e definhou, olhando-se e se embelezando. Após a morte de Narciso, as deusas o transformaram numa flor, que depois receberia seu nome.

E como bem diz a música de Caetano Veloso, "Narciso acha feio o que não é espelho". Assim igualmente é a colonialidade, que extermina o que lhe for dessemelhante. Assim, a partir do pensamento de Carla Akotirene (2019), indagamos que Oxum não poder ser representada, de forma alguma, por Narciso, ou como narcisista, visto que ele próprio é uma representação da colonialidade, da cultura gregoromana e europeia, insígnias de mesquinharia e infertilidade. Enquanto Oxum, o contrário, é uma representação de pelejas antirracistas e anti-machistas, da cultura afrobrasileira, insígnia de generosidade e de fertilidade ${ }^{3}$.

Além das referências das religiões afro-brasileiras, são fundamentais as úmidas perspectivas de Oyèrónkẹ́ Oyěwùmí (2017) e de Wanderson Flor do Nascimento (2019). Considerando a elocução de que "o ventre de Oxum pare poder", os/as autores/as nos explicam que matrigeradoras e matrigestoras seriam as potencialidades de gestação e de gestão de potencialidades, por exemplo, das comunidades tradicionais afro-brasileiras, observando que: I) isso não está relacionado exclusivamente à perspectiva biológica; II) não está relacionado à paridade de prole e III) mas está

\footnotetext{
${ }^{3}$ AKOTIRENE, Carla. Oxum. Postagem no Instagram. https://www.instagram.com/p/B-ws3Anlkop/ em 09 de abr. de 2020.
} 
relacionado à ancestralidade (AKOTIRENE, 2019; OYĚWÙMÍ, 2017; NASCIMENTO, 2019; RIBEIRO, 2020).

Carla Akotirene tem insistido que "Oxum usa seu Abebê para enxergar o mundo às suas costas" (2019). Oxum, além de uma estratégia bélica, usa seu Abebé como Sankofa, que é um elemento de um conjunto de ideogramas chamados Adinkra, representado por um pássaro que volta a cabeça à cauda. O símbolo é traduzido por "retornar ao passado para resinificar o presente e construir o futuro" (NASCIMENTO; GÁ, 2009). Conceição Evaristo, em Olhos D'Água, igualmente escreveu sobre espelhos: "os olhos de uma são o espelho dos olhos da outra" (EVARISTO, 2016, p.16). E acreditamos que podemos relacionar essas elocuções com as perspectivas do seguinte Itan $^{4}$, coletado por Reginaldo Prandi, em pesquisa de campo em São Paulo em 1997. Nas religiões afro-brasileiras Oxum Apará usa roupas cor-de-rosa, com ferramentas feitas de latão, que são atributos de Oyá:

Vivia Oxum no palácio de Ijimu. Passava os dias no seu quarto olhando seus espelhos. Eram conchas polidas onde apreciava sua imagem bela. Um dia saiu Oxum quarto e deixou a porta aberta. Sua irmã Oyá entrou no aposento, extasiou-se com aquele mundo de espelhos, viu-se neles. As concas fizeram espantosa revelação a Oyá. Ela era linda! A mais bela! A mais bonita de todas as mulheres! Oyá descobriu sua beleza nos espelhos de Oxum. Oyá se encantou, mas também se assustou: era ela mais bonita que Oxum, a Bela. Tão feliz ficou que contou do seu achado a todo mundo. E Oxum Apará remoeu amarga inveja, já não era a mais bonita das mulheres. Vingou-se. Um dia foi à casa de Egungun e lhe roubou o espelho, o espelho que só mostra a morte, a imagem horrível de tudo o que é feio. Pôs o espelho do Espectro no quarto de Oyá e esperou. Oyá entrou no quarto, deu-se conta do objeto. Oxum trancou Oyá pelo lado de fora. Oyá olhou no espelho e se desesperou. Tentou fugir, impossível. Estava presa com sua terrível imagem [...] Obatalá, que a tudo assistia, repreendeu Apará e transformou Oyá em orixá. Decidiu que a imagem de Oyá nunca seria esquecida por Oxum. Obatalá, condenou Apará a se vestir para sempre com as cores usadas por Oyá levando nas jóias e nas armas de guerreira o mesmo metal empregado pela irmã (PRANDI, 2020, p.323).

Além das características descritas no Itan por Reginaldo Prandi, Oxum Opará, como igualmente é conhecida, adorna-se nas religiões afro-brasileiras com dois espelhos, um que mostra apenas as coisas boas e outro que mostra apenas as ruins. Para qual estamos olhando? Aníbal Quijano ponderou que ainda estamos olhando para o "espelho das coisas ruins", o "espelho eurocêntrico" (QUIJANO, 2005, p.139).

\footnotetext{
${ }^{4}$ Mito afro-brasileiro.
} 
Considerando que Franz Fanon, em Pele Negra, Máscaras Brancas, indagou que "os negros buscam a ilusão dos espelhos que oferecem um reflexo branco" (2008, p.15). Quijano, em Colonialidade do poder, Eurocentrismo e América Latina, ponderou a respeito do espelho eurocêntrico:

\begin{abstract}
Aplicada de maneira específica à experiência histórica latinoamericana, a perspectiva eurocêntrica de conhecimento opera como um espelho que distorce o que reflete. Quer dizer, a imagem que encontramos nesse espelho não é de todo quimérica, já que possuímos tantos e tão importantes traços históricos europeus em tantos aspectos, materiais e intersubjetivos. Mas, ao mesmo tempo, somos tão profundamente distintos. Daí que quando olhamos nosso espelho eurocêntrico, a imagem que vemos seja necessariamente parcial e distorcida. Aqui a tragédia é que todos fomos conduzidos, sabendo ou não, querendo ou não, a ver e aceitar aquela imagem como nossa e como pertencente unicamente a nós. Dessa maneira seguimos sendo o que não somos. E como resultado não podemos nunca identificar nossos verdadeiros problemas, muito menos resolvê-los, a não ser de uma maneira parcial e distorcida (QUIJANO, 2005, pp.129-130).
\end{abstract}

Sugerimos que empregar o "espelho afro-brasileiro" de Oxum, o Abebé, como potência matrigeradora e matrigestora, apropriado para dar subsídio às empreitadas decoloniais $^{5}$ (LANDER, 2005), especialmente as antirracistas e anti-machistas. Ponderamos acerca das reflexões de Wanderson Flor do Nascimento a respeito da Ikupolítica (2020) - e de Luiz Antonio Simas e Luiz Rufino, com a noção de desencanto (2019), teses e contribuições que têm nos servido como espelhos contraeurocêntricos. Aníbal Quijano, ainda refletindo sobre os espelhos, tem salientado que é tempo de "aprendermos a nos libertar do espelho eurocêntrico onde nossa imagem é sempre, necessariamente, distorcida. É tempo, enfim, de deixar de ser o que não somos" (QUIJANO, 2005, p.139).

José Saramago, na ficção Ensaio sobre a Cegueira (1995), retrata uma doença chamada cegueira branca, que se alastra por uma localidade e atinge um enorme número de sujeitos, causando padecimento humanitário. Igualmente ao Itan anterior mencionado, gostaríamos de relacioná-los ao mito coletado por Sérgio Ferretti, durante pesquisa de campo em São Luís no Maranhão em 1997, narrado por Pai Jorge Itaci,

\footnotetext{
${ }^{5}$ Luciana Ballestrin explica que "descolonial" ou decolonial não deve ser confundida como mera descolonização. "Em termos históricos e temporais, esta última indica uma superação do colonialismo; por seu turno, a ideia de decolonialidade ou descolonialidade procura transcender a colonialidade, a face obscura da modernidade, que permanece operando ainda nos dias de hoje em um padrão mundial de poder" (BALLESTRIN, Luciana. Para transcender a colonialidade. Revista IHU on-line, v. 431, p. 40-41, 2013).
} 
chefe do terreiro Mina de Iemanjá. Navezuarina, ou Navê, Dantã e Queviossô são voduns ${ }^{6}$ cultuados no Tambor de Mina:

Um dia houve uma grande guerra entre as tribos. Nessa guerra os soldados aprisionaram diversas moças. Uma delas era uma virgem chamada Navezuarina. Quando os raptores levavam as moças aprisionadas, Navezuarina invocou uma força mágica, e fez surgir um intensíssimo clarão. O clarão cegou os guerreiros que levavam as prisioneiras. Os soldados ficaram perambulando no mato, sem direção. Como eles já nada enxergavam, elas pensaram em fugir e voltar para sua aldeia. Navezuarina, que é outro nome de Oxum, pegou e preparou uma poção com ervas. Ela passou a mistura nos olhos dos guerreiros e eles recobraram a visão. Agradecidos, soltaram todas as prisioneiras. Elas voltaram ao seu lar no país dos nagôs. Navezuarina voltou para casa com as amigas, voltou em companhia de Dantã e outras. Todas voltaram para sua aldeia, onde são sacerdotisas da casa de Queviossô. E elas andam juntas até hoje, usando sempre roupas cor-de-rosa (PRANDI, 2020, p.326).

A cegueira branca (SARAMAGO, 1995) podemos comparar com a colonialidade (LANDER, 2005), ou seja, com uma patologia da humanidade que muitas vezes vigora pelo fato dos sujeitos não quererem enxergar, alienando-se com relação a si próprios. Mas, na maior parte das vezes, a cegueira - ou a colonialidade - é consequência de um processo projetado de colonialismo que continuamente pretere os seres e os saberes subalternizados (LANDER, 2005).

Talvez essa seja uma maneira possível para interpretarmos o Itan: lembremonos de que Oxum teria cegado com um clarão guerreiros que mantinham ela e outras prisioneiras, mas, posteriormente, por meio de encantamentos ela mesma teria recomposto a visão dos sujeitos. Como metáfora e/ou metonímia, acreditamos que Oxum pode contribuir para arrancar a cegueira dos/as subalternizados/as, cegueira que corrobora com a colonialidade consciente e inconscientemente; mas, assim como fez com os guerreiros usando seus encantamentos, a deusa alerta para o fato de que precisamos nos valer dessas potências ancestrais das religiões afro-brasileiras para nos libertar da colonialidade - cegueira branca - junto aos/as nossos/as assemelhados/as. Afinal, como diz a canção de Ordep Serra gravada na voz de Maria Bethânia, “Oxum é água que aparta a morte". Podemos usar o abebé de Oxum como perspectiva para mirarmos alternativas decoloniais: com o espelho de Oxum podemos olhar para trás e para frente ao mesmo tempo, vislumbrando um futurismo ancestralizado.

\footnotetext{
${ }^{6}$ Divindades afro-brasileiras oriundas das culturas Nagô e Ewe-Fon.
} 
Como insígnias de Iyás que se valeram das potências e ancestralidades afrobrasileiras, seja de Oxum ou de outras divindades, a seguir dispomos breves notas biográficas de mães de santo e mulheres de terreiro, matrigestoras e matrigeradoras, que usaram as ferramentas sagradas dos orixás - isto é, os aladás de Ogum, os ofás de Oxóssi, os xaxarás de Obaluaiê e Omolu, os ibiris de Nanã, os eruexins de Oyá, os abebés de Oxum e Iemanjá, os oxés de Xangô e os atoris e opaxorôs de Oxalá - nas lutas antirracistas e feministas. E, se os 12 Ojú Obá (os cargos de conselheiros ilustres, Ministros de Xangô consagrados por Mãe Aninha do Ilê Axé Opó Afonjá em 1936) homenageiam os espectros masculinos afro-brasileiros, as 12 Iyás aqui memoradas homenageiam as Iyábás, divindades femininas afro-diaspóricas.

\section{Notas biográficas}

Mães de santo e/ou mulheres de terreiro possuem centralidade na construção cultural no Brasil e, por isto, consideramos fundamental rememorá-las. Recontar suas trajetórias, recompor seus itinerários sócio-religiosos e partilhar suas experiências. A despeito do processo de invisibilização social, identificamos que as lutas antirracistas e feministas são comuns nas vidas dessas Iyás, verificamos que em diferentes períodos e em diferentes terreiros essas lutas se repetiram de distintas formas e compreendemos que as lutas contra o racismo e o machismo são constitutivas - ou ao menos se apresentam como características centrais - das Iyás afro-brasileiras.

Valdina de Oliveira Pinto ficou conhecida como Makota Valdina, ou Makota Zimewaanga, seu nome iniciático. Em 1975 foi iniciada no candomblé de raiz Angola, no Terreiro Tanuri Junsara, como Makota, o mesmo cargo que Ekedi ou Ajoie, que é a autoridade religiosa que auxilia outros/as religiosos/as e as divindades afro-brasileiras, permanecendo acordadas, sem entrar em transe. Nasceu em Salvador, em 1943, foi educadora, líder comunitária e ativista dos Direitos Humanos e atuou essencialmente nas causas antirracistas e feministas. Recebeu as honras do Troféu Clementina de Jesus, da União de Negros Pela Igualdade (UNEGRO), do Troféu Ujaama, do grupo Cultural Olodum, da Medalha Maria Quitéria, da Câmara Municipal de Salvador e de Mestra Popular do Saber, pelo Ministério da Cultura do Brasil. Protagonizou o documentário Makota Valdina - Um jeito Negro de Ser e Viver, que recebeu o Prêmio Palmares de Comunicação, da Fundação Cultural Palmares. Faleceu em 2019, em Salvador, Bahia. 
Makota Valdina dizia que "não sou descendente de escravos; eu descendo de seres humanos que foram escravizados" (2012). Integrou o Conselho Estadual de Cultura da Bahia.

Maria Genoveva do Bonfim ficou conhecida como Maria Neném ou Mam'etu Tuenda Dia Nzambi, e foi consagrada ao nkisi Kavungo, uma divindade banta retentora da terra. Nasceu em 1865 no Rio Grande do Sul e faleceu em 1945, em Salvador, Bahia. Filha de santo de Roberto Barros Reis, conhecido como Tata Kimbanda Kinunga, africano que foi escravizado no Brasil, e dele herdou o Nzo Tumbensi, afamado terreiro de liturgia Angola mais antigo da Bahia. Maria Neném foi a matriarca de muitos religiosos que originaram outras grandes comunidades afro-brasileiras, como o Terreiro Tumba Junsara e o Terreiro do Bate-Folha (ambos tombados pelo Instituto do Patrimônio Histórico e Artístico Nacional), o Terreiro Tanuri Junsara e muitos outros no Brasil (ADOLFO, 2009).

Maria Valentina dos Anjos Costa ficou conhecida como Doné Runhó, ou Mãe Ruinhó, e foi consagrada ao vodun Sogbô, divindade Jeje-Mahi das trovoadas e dos raios. É descendente de africanos procedentes do antigo Daomé que confluíram a Revolta dos Malês, ocorrida em Salvador em 1835, um levante significativo no Brasil protagonizado por pessoas escravizadas que lutavam contra a situação em que viviam, muitos de origem islâmica. Doné Runhó foi a quarta mãe de santo do Terreiro do Bogun, ou Zoogodô Bogun Malê Rundó em Salvador, Bahia. O nome da praça do Engenho Velho da Federação, na capital bahiana, é uma homenagem à memória de Doné Runhó (PARÉS, 2018).

Hilária Batista de Almeida ficou conhecida como Tia Ciata e nasceu em Santo Amaro, na Bahia, em 1854. Filha de Oxum, divindade que reina sobre as águas doces, aos 22 anos mudou-se para o Rio de Janeiro. Tia Ciata foi mãe carnal de quinze filhos e mãe de santo de muitos outros. Era doceira e vendia seus quitutes em um tabuleiro, vestida com a indumentária tradicional de baiana, com saia, pano de cabeça e pano da costa. Numa época em que a libertação dos escravizados ainda era recente e que as religiões afro-brasileiras e a capoeira eram indesejadas e malquistas, Tia Ciata acolhia em sua casa - na "Pequena África", como era conhecido seu bairro no Rio de Janeiro africanos e seus descendentes e, da mesma forma, imigrantes europeus paupérrimos recém-chegados ao Brasil. Em 1916, os tambores afro-brasileiros juntaram-se aos violões italianos e aos cavaquinhos portugueses na casa de Tia Ciata para a produção de Pelo Telefone, considerado o primeiro samba a ser gravado no Brasil, de autoria de 
Donga e Mauro Almeida. Entre 1920 e 1930 era significativo que as escolas de samba passassem pela Praça Onze e pela casa de Tia Ciata para homenageá-la. A famosa Ala das Baianas nas Escolas de Samba é uma referência à Tia Ciata e a outras senhoras consideradas mães do samba (SIMAS, 2018).

Eugênia Anna Santos ficou conhecida como Mãe Aninha e nasceu em Salvador, na Bahia, em 13 de julho de 1869, filha de Xangô, divindade da justiça, dos raios, do trovão e do fogo. Foi iniciada na Casa Branca do Engenho Velho, o Ilê Axé Iyá Nassô Oká, tombado em 1984 como patrimônio nacional. Em 1869 fundou o Ilê Axé Opô Afonjá em Salvador, tombado patrimônio em 2000, e em 1895 fundou o Ilê Axé Opô Afonjá no Rio de Janeiro. Em 1934, Mãe Aninha conversou com Getúlio Vargas - o Chefe do Governo Provisório — sobre a coibição que as religiões afro-brasileiras sofriam e, consequentemente, essas religiões foram descriminalizadas. Em 1936, Mãe Aninha instituiu o Corpo dos Obás de Xangô, os chamados Ministros do Rei, títulos honoríficos e diplomáticos afro-brasileiros com funções diplomáticas e políticas dentre os quais já ocuparam funções Dorival Caymmi, Carybé, Jorge Amado, Vivaldo da Costa Lima, Muniz Sodré e Gilberto Gil. Eles são os Ojú Obá, os olhos do rei, no Ilê Axé Opô Afonjá. Além destas contribuições, Mãe Aninha participou do II Congresso AfroBrasileiro em 1937, falando sobre alimentação nas religiões afro-brasileiras (SANTOS, 2007).

Francisca Xavier Queiroz de Jesus é conhecida como Chica Xavier e nasceu em 22 de janeiro de 1936, em Salvador, Bahia. É atriz, dedicada ao teatro, cinema e televisão. Filha de Iansã, divindade dos ventos e do fogo, é também mãe de santo da Jurema, uma expressão religiosa afro-ameríndia brasileira, em seu terreiro Irmandade do Cercado do Boiadeiro, no Rio de Janeiro. É casada com o ator Clementino Kelé desde 1956 e foi precursora e insígnia de gerações de atores e atrizes negros- Estreou em 1956 no Teatro Municipal do Rio de Janeiro com Orfeu da Conceição, que marcou o início da parceria de Vinícius de Moraes e Tom Jobim, com cenários de Oscar Niemeyer. Na Rede Globo de Televisão interpretou mais de cinquenta personagens e entre seus trabalhos estão, por exemplo, as novelas A cabana do Pai Tomás (1969); Tenda dos Milagres (1985); Dancin Days (1978); Sinhá Moça (1986); Força de um Desejo (1999) e A Lua me Disse (2005). Em 1999 escreveu o livro Chica Xavier canta sua prosa, que reuniu cantigas e preces para santos católicos e das religiões afro-brasileiras. Em 2011, foi homenageada com o Centro Cultural Atriz Chica Xavier, em Ramos, no Rio de Janeiro, e, em 2013, Teresa Monteiro escreveu sua biografia, Chica Xavier: Mãe do Brasil. A 
importância da atuação de Chica Xavier para o povo de axé se dá, entre outros motivos, pela representatividade negra, de uma mãe de santo, na televisão e no teatro (MONTERO, 2013).

Conhecida como Odé Kayodé, o caçador que traz alegrias, Maria Stella de Azevedo Santos, conhecida como Mãe Stella de Oxóssi era filha do orixá-caçador da fauna e da fartura e nasceu em 02 de maio de 1925, em Santo Antônio de Jesus, na Bahia. Foi a quinta sacerdotisa do Ilê Axé Opô Afonjá em Salvador, que liderou entre 1976 e 2018, como sucessora de Mãe Ondina, que permaneceu no posto entre 1969 e 1975, após os reinados de Mãe Aninha, a grande fundadora; de Mãe Badá, entre 1939 e 1941 e de Mãe Senhora, entre 1942 e 1967. Mãe Stella era Doutora Honoris Causa pela Universidade do Estado da Bahia e Membra da Academia de Letras da Bahia. Instituiu a Escola Municipal Eugênia Anna Santos e o Museu Ilê Ohun Lailai. Mãe Stella divulgou as religiões afro-brasileiras por meio de seus livros, participou de espaços de discussão e decisão como liderança religiosa e como intelectual. Odé Kayodé foi uma Agbá, isto é, insígnia da ancestralidade afro-brasileira (SANTOS, 1993).

Maria Escolástica da Conceição Nazaré, que tem esse nome em homenagem à Nossa Senhora Escolástica, é conhecida no Brasil como Mãe Menininha do Gantois. Nasceu em Salvador em 1894 e era filha de Oxum, divindade da beleza, do amor, da fertilidade e da maternidade. Entre 1922 e 1986 foi a Iyálorixá do Ilê Iyá Omi Asé Iyamassê, o Terreiro do Gantois, tombado patrimônio em 2002, fundado e instituído por sua antepassada, Maria Júlia da Conceição Nazaré. Entre 1930 e 1940, período em que as religiões afro-brasileiras padeciam com perseguição e violência policial na Bahia, Mãe Menininha consentiu que intelectuais, artistas, políticos e religiosos de outras denominações frequentassem o Terreiro do Gantois, contribuindo para a popularização das religiões afro-brasileiras. Gal Costa, Caetano Veloso e Maria Bethânia são alguns dos famosos filhos de santo de Mãe Menininha, apelidada de Mão da Doçura. Recebeu muitas homenagens, como a de Dorival Caymmi, que compôs, em 1972, Oração de Mãe Menininha: "e a Oxum mais bonita, hein? / Tá no Gantois [...] Ai, Minha Mãe / Minha Mãe Menininha [...]". Igualmente, a famosa canção É D'Oxum, composta por Gerônimo e Vevé Calazans em 1992, teve Mãe Menininha do Gantois como homenageada em seus versos: "nessa cidade todo mundo é d'Oxum / Homem, menino / Menina, mulher". Jorge Amado, no livro Bahia de Todos os Santos (1945), escreveu que Mãe Menininha era a mãe do povo da Bahia e a mãe do povo do Brasil (NÓBREGA; ECHEVERRIA, 2006). 
Olga Francisca Régis é conhecida como Olga do Alaketu, e seu nome religioso no candomblé é Oyá Funmi. Nasceu em 09 de setembro de 1925, em Salvador, e era descendente da família real Arô, do antigo reino de Ketu, no atual Benin, na África. Era filha de Iansã, divindade do vento, do fogo e das tempestades, e por 57 anos foi a mãe de santo do terreiro do Alaketu, o Ilê MarOyá Láji em Salvador, tombado em 2005. Contam os velhos-que duas princesas gêmeas, ainda crianças, foram enclausuradas e depois escravizadas na Bahia durante a diáspora negra-africana. Uma dessas meninas era Iyá Gogorisá e a outra era Iyá Otampê Ojarô, que passou a se chamar Maria do Rosário Francisca Régis, e que após sua alforria teria voltado para África e se casado com Babá Láji, com quem voltou para Salvador e fundou o Terreiro do Alaketu, o Ilê MarOyá Láji. A princesa africana Otampê Ojarô, ou Maria do Rosário Francisca Régis, era a tia-avó de Olga do Alaketu. Em 1997, Mãe Olga recebeu pelo então Presidente do Brasil, Fernando Henrique Cardoso, a Ordem do Mérito Cultural, uma condecoração outorgada pelo Ministério da Cultura a pessoas, grupos artísticos, iniciativas ou instituições a título de reconhecimento por suas contribuições à cultura brasileira (CASTILLO, 2011).

Beatriz Moreira Costa é conhecida como Mãe Beata de Iemanjá e nasceu em 20 de janeiro de 1931, em Cachoeira, na Bahia. Era filha de Iemanjá, divindade das águas e mãe dos peixes, e de Exu, mensageiro e dono das encruzilhadas. Foi filha de santo de Mãe Olga do Alaketu no Ilê MarOyá Láji. Em 1969, separou-se de seu companheiro, saiu de Cachoeira e foi para o Rio de Janeiro, cidade na qual trabalhou como atriz e figurinista em novelas da Rede Globo de televisão até a sua aposentadoria. Em 20 de abril de 1985, Mãe Olga do Alaketu consagrou Mãe Beata de Iemanjá como mãe de santo do Ilê Omiojuarô, no Rio de Janeiro. Foi ativista pelos Direitos Humanos, em especial os direitos das mulheres negras, e escreveu os livros Caroço de Dendê, Sabedoria dos Terreiros (1997) e As histórias que minha avó contava (2005). Em 2006, Glória Cecília de Souza Filho escreveu a tese de doutorado em Educação na Universidade Estadual do Rio de Janeiro Os Fios de Contos de Mãe Beata de Iemanjá: Mitologia Afro-brasileira e Educação. Mãe Beata também foi conselheira da Rede Nacional de Religiões Afro-Brasileiras e Saúde. Recebeu a Medalha de Mérito Cívico Afro-Brasileiro, conferida pela Universidade da Cidadania Zumbi dos Palmares de São Paulo. Em 2007, recebeu o Prêmio Bertha Lutz, que foi instituído pelo Senado Federal do Brasil para agraciar mulheres que tenham oferecido relevante contribuição na defesa dos direitos sexuais e reprodutivos. Em 2017, receberia a Medalha Tiradentes da Assembleia Legislativa do Rio de Janeiro, que é uma honraria concedida e destinada a 
premiar pessoas que prestaram relevantes serviços pela causa pública do Estado do Rio de Janeiro. Mãe Beata faleceu em 27 de maio de 2017, e a homenagem foi mantida e recebida por seus filhos (COSTA, 2002; 2004).

O Dia Nacional de Combate à Intolerância Religiosa, instituído em 2007, homenageia Gildásia dos Santos, conhecida como Mãe Gilda, que foi a fundadora do Axé Abassá de Ogum, em Itapuã, na Bahia. Mãe Gilda teve sua imagem usada numa edição de 1999 da Folha Universal, uma publicação da Igreja Universal do Reino de Deus, ao lado da manchete Macumbeiros Charlatões Lesam a Bolsa e a Vida dos Clientes - O Mercado da Enganação Cresce no Brasil, mas o Procon Está de Olho. Esse fato, somado a invasão de seu terreiro por membros da Igreja Deus é Amor que tentaram exorcizá-la, levou a mãe de santo a decidir por mover uma ação judicial contra seus agressores e difamadores. Mãe Gilda faleceu em seguida, aos 65 anos, de um infarto fulminante em consequência desses acontecimentos, que conforme sua família a abalaram profundamente. Em 2004, a IURD e sua gráfica foram condenadas a indenizar a família de Mãe Gilda em R $\$ 1,372$ milhão pelo uso indevido de sua imagem, sendo um real por cada exemplar do jornal publicado com a matéria difamatória. O caráter emblemático deste caso levou nesse mesmo ano a Câmara de Vereadores de Salvador a transformar a data de falecimento da mãe de santo, 21/01/2000, em Dia Municipal de Combate Intolerância Religiosa. Seu legado e sua luta têm continuidade com Mãe Jaciara, que atualmente organiza ebós coletivos em protestos contra o racismo religioso (SILVA, 2007).

Giselle Cossard Binon é conhecida como Omindarewa e nasceu em 31 de maio de 1923, em Tanger, no Marrocos. Viveu por muitos anos na França, como alude sua biografia Omindarewa: Uma Francesa no Candomblé, escrita por Michel Dion, em 2002. Em 1939, durante a Segunda Guerra Mundial, Giselle viu seu pai ser preso pelo exército de Adolf Hitler e, no fim da guerra, em 1945, teria sido espiã em Paris, fornecendo informações aos militares franceses sobre a localização de militares alemães. Em 1945 seu pai voltou da prisão e Giselle casou-se com Jean Binon, com quem passou oito anos na África. Em 1956, voltaram para França e Jean Binon foi nomeado Embaixador da França no Brasil. Omindarewa, assim como seus filhos, encantaram-se com o Rio de Janeiro e com o país. Mas, contrariamente e conflituosamente, Jean Binon detestava o Brasil e os brasileiros- Em 5 de dezembro de 1959, Giselle Cossard Binon visitou o terreiro de Joãozinho da Goméia, no Rio de Janeiro, onde bolou no santo, isto é, recebeu em transe pela primeira vez sua divindade, Iemanjá, que é mãe das águas e dos 
peixes. Após passar pelas cerimônias de iniciação afro-brasileiras, recebeu seu nome religioso de Omindarewa, que podemos traduzir como "água límpida". Jean Binon em 1963 pediu divórcio a Giselle, e no mesmo ano Omindarewa voltou para França, para apresentar sua tese Contribution à l'Étude des Candomblés du Brésil: Le Rite Angola em Paris, e lá tornou-se docente universitária. Conheceu o fotógrafo e etnólogo Pierre Verger, do qual se tornou amiga. Em 1972, voltou para o Brasil e, em 1973, sofreu um acidente de carro e foi diagnosticada sem esperança de vida. Pierre Verger levou Omindarewa até Pai Balbino Daniel de Paula, Balbino de Xangô Obaraí, iniciado no Terreiro do Opô Afonjá, que ajudou a filha de Joãozinho. Pai Obaraí tornou-se o segundo pai de santo de Omindarewa, passando a cuidar de suas obrigações religiosas. Ao receber seus direitos de sacerdotisa, fundou o Ilê Axé Atará Magba, em Duque de Caxias, no Rio de Janeiro. Em 2005, participou do documentário A cidade das mulheres, e, em 2009, do documentário Gisele Omindarewa que trata sobre sua biografia. Faleceu em 2016 (DION, 2002; COSSARD, 2008).

\section{Considerações finais}

O filósofo martiniquense Frantz Fanon, em um texto de intervenção para o Primeiro Congresso de Escritores e Artistas Negros, que ocorreria em Paris, em 1956, argumentou como o sofrimento, as relações de poder e a violência racial são estetizadas e se tornam obras de arte que depois têm grande apelo de público, constituindo-se, inclusive, em gênero artístico. Ele se referia especificamente ao blues e ao jazz que de alguma maneira falam do sofrimento dos negros, mas é possível também pensar nos filmes que tratam da escravidão, que mobilizam emocionalmente seus espectadores, causam reações de indignação e provocam debates a respeito da vida social. Nesta direção é fundamental recuperar trajetórias exemplares, vidas vividas de maneira autopoética, que possam inspirar intinerários biográficos escritos em nosso cotidiano.

Isso se faz necessário porque as pessoas se moldam, se constituem enquanto sujeitos, posicionando-se a partir de uma cultura racista e não apesar dela. A vida destas mulheres nos ensina que o rechaço, o medo, a conduta discriminatória já não são do sujeito particular, mas uma certa forma de existir, típica da nossa sociedade. Existir e resistir tornam-se sinônimos, neste cenário. A resistência é um grito de vida nesse processo de espoliação. 
Ansiamos que, ao mencionar aqui elementos das vidas dessas mães de santo e mulheres de terreiro, tenha ficado compreensível que essas Iyás são exemplares das potências matrigeradoras e matrigestoras afro-brasileiras, em que entendemos Iyábá Oxum como sua insígnia conspícua. Esperamos ter refletido que, assim como Oxum e seu abebé são efetivamente belicosos, e que apesar de suas representações serem erroneamente distorcidas pela colonialidade, há de se lembrar do que elucida o provérbio africano citado por Wanderson Flor do Nascimento (2020): "o ventre de Oxum pare poder". Ademais, também é mister lembrar como canta o Ijexá: a Ekó a e Egué e Iyálode Iyá Awo Orô, Orun o Yeye o, Iyá Monlé Odo, Oxum Ilê Opô, traduzido como "nós lhe oferecemos ekó, pois ela pode tornar-se uma perigosa armadilha, ela é a primeira Iyá, Iyábá do rio, Oxum é o pilar que sustenta a nossa casa”.

\section{Glossário}

Abebé: Espelho de mão de Oxum e de Iemanjá.

Adinkra: São símbolos africanos desenvolvidos pelos Akan (povos localizados em Gana, Costa do Marfim e no Togo, países da África do Oeste), que se destacam pela utilização de símbolos para transmitir ideias.

Agogô: Instrumento musical de metal, que possui sinos, percutido com metal ou madeira.

Aladá de Ogum: Facão, ferramenta de Ogum, divindade afro-brasileira guerreira.

Atori e Paxorôs de Oxalá: Cetros, ferramentas de Oxalá, divindade afrobrasileira anciã.

Calunga Grande: Oceano.

Eruexin de Oyá: Cetro, ferramenta de Oyá, divindade afro-brasileira dos ventos.

Ibiri de Nanã: Cetro, ferramenta de Nanã, divindade afro-brasileira do barro.

Ijexá: Ritmo musical religioso afro-brasileiro consagrado a Oxum e outros/as divindades.

Itan: Mito.

Iyá/Iyás: Mãe, Mães.

Iyábás/Ayabás: Divindades afro-brasileiras mães. 
Ofá de Oxóssi: Arco e flecha, ferramenta de Oxóssi, divindade afro-brasileira caçadora.

Opará/Apará: Epíteto de Oxum.

Oxé de Xangô: Machado, ferramenta de Xangô, divindade afro-brasileira da justiça.

Oxum: Divindade afro-brasileira das águas doces.

Oyá: Divindade afro-brasileira dos ventos.

Sankofa: Elemento de um conjunto de ideogramas chamados Adinkra, representado por um pássaro que volta a cabeça à cauda. $\mathrm{O}$ símbolo é traduzido por retornar ao passado para ressignificar o presente e construir o futuro.

Xaxará de Obaluaiê e Omolu: Cetro, ferramenta de Obaluaiê e Omolu, divindades afro-brasileiras da terra.

\section{Referências}

A CIDADE DAS MULHERES. Direção: Lazaro Faria. Salvador: Casa de Cinema da Bahia, 2005.

ADOLFO, Sergio Paulo. Tata Kisaba Kiundundulu. Maria Genoveva do Bonfim: $O$ Nascimento da Nação Congo/Angola no Brasil. Ombala Tumbansi [Online]. Itapecerica da Serra: Nzo Tumbansi, 2009. Disponível em: <http://inzotumbansi.org/home/mariagenoveva-do-bonfim-o-nascimento-da-nacao-congoangola-no-brasil/> .

AKOTIRENE, Carla. Interseccionalidade. São Paulo: Pólen, 2019.

BALLESTRIN, Luciana. "Para transcender a colonialidade". Revista IHU [on-line], vol.431, 2013.

CASTILLO, Lisa Earl. "O terreiro do Alaketu e seus fundadores: história e genealogia familiar". Afro-Ásia, n.43, 2011.

COSSARD, Gisele Omindarewá. Awó: o mistério dos orixás. Rio de Janeiro: Pallas, 2008.

COSTA, Beatriz Moreira. Caroço de dendê: a sabedoria dos terreiros: como ialorixás e babalorixás passam conhecimentos a seus filhos. Rio de Janeiro: Pallas, 2002.

COSTA, Beatriz Moreira. Histórias que minha avó contava. Rio de Janeiro: Terceira Margem, 2004.

DION, Michel. Omindarewa: uma francesa no candomblé: a busca de uma outra verdade. Rio de Janeiro: Pallas, 2002.

EVARISTO, Conceição. Olhos d'água. Rio de Janeiro: Pallas, 2016. 
FANON, Frantz. Pele negra, máscaras brancas. Salvador: EDUFBA, 2008.

GROSFOGUEL, Ramón (comp). El Giro Decolonial: reflexiones para uma diversidad epistémica más allá del capitalismo global. Bogotá: Universidad Javeriana-Instituto Pensar, Universidad Central-IESCO, Siglo del Hombre, 2007.

GISĖLE OMINDAREWA. Direção: Clarice Ehlers Peixoto. Rio de Janeiro: FAPERJ Fundação Carlos Chagas Filho de Amparo à Pesquisa do Estado do Rio de Janeiro, 2009.

HALL, Stuart. "Identidade cultural e diáspora". Revista do patrimônio histórico e artístico nacional, v. 24, n. 1, 1996.

LANDER, Edgardo et al. (Ed.). A colonialidade do saber: eurocentrismo e ciências sociais: perspectivas latino-americanas. Buenos Aires: CLACSO, 2005.

MAKOTA VALDINA - UM JEITO NEGRO DE SER E VIVER. Direção: Joyce Rodrigues. Brasília: Fundação Cultural Palmares, 2012.

MIGNOLO, Walter. Histórias Locais / Projeto Globais - Colonialidade, Saberes Subalternos. Belo Horizonte: Editora UFMG, 2003.

MONTERO, Teresa. Chica Xavier: Mãe do Brasil. Rio de Janeiro: Eldorado, 2013.

NASCIMENTO, Elisa Larkin; GÁ, Luiz Carlos. Adinkra - Sabedoria em Símbolos Africanos. Rio de Janeiro: Pallas, 2009.

NASCIMENTO, Wanderson Flor do. "Oyèrónkẹe Oyěwùmí: Potências Filosóficas de uma Reflexão". Problemata, vol.10, n.2, 2019. Disponível em: <doi:http://dx.doi.org/10.7443/problemata.v10i2.49121>.

NASCIMENTO, Wanderson Flor do. "Da Necropolítica à Ikupolítica". Revista Cult Dossiê Filosofia e Macumba, 2020.

NÓBREGA, Cida; ECHEVERRIA, Regina. Mãe Menininha do Gantois: uma biografia. Rio de Janeiro: Ediouro, 2006.

OYĚWÙMÍ, Oyèrónkẹ. La invención de las mujeres. Una perspectiva africana sobre los discursos occidentales del género. Bogotá: La Fronteira, 2017.

PARÉS, Luis Nicolau. A formação do candomblé: história e ritual da nação jeje na Bahia. Campinas: UNICAMP, 2018.

PRANDI, Reginaldo. Mitologia dos orixás. São Paulo: Companhia das Letras, 2020.

QUIJANO, Anibal. "Colonialidade do poder, eurocentrismo e América Latina". Colección Sur Sur, CLACSO, pp.107-130, 2005.

QUIJANO, Anibal. "Colonialidad del Poder, Cultura y Conocimiento en América Latina”. Anuário Mariateguiano, Vol.9, n.9, 1997. 
RIBEIRO, Katiuscia. "Mulheres Negras e a força matricomunitaria". Revista Cult Dossiê Filosofia e Macumba, 2020.

RUFINO, Luiz. Pedagogia das Encruzilhadas. Rio de Janeiro: Mórula Editorial, 2019. SANTOS, João Baptista Tobiobá dos. "21 Cartas e um telegrama de mãe Aninha a suas filhas Agripina e Filhinha, 1935-1937”. Afro-Ásia, n.36, 2007.

SANTOS, Maria Stella de Azevedo. Meu tempo é agora. São Paulo: Editora Oduduwa, 1993.

SARAMAGO, José. Ensaio sobre a cegueira. São Paulo: Companhia das Letras, 1995.

SIMAS, Luiz Antônio; RUFINO, Luiz. Flecha no tempo. Rio de Janeiro: Mórula Editorial, 2019.

SIMAS, Luiz Antônio; RUFINO, Luiz. Fogo no Mato: a ciência encantada das macumbas. Rio de Janeiro: Mórula Editorial, 2019.

SIMAS, Luiz Antônio. Almanaque Brasilidades, Um Inventario do Brasil Popular. Rio de Janeiro: Bazar do Tempo, 2018.

SILVA, Anaxsuell F.; PROCÓPIO, C. "Colonialidades do crer, do saber e do sentir: apontamentos para um debate epistemológico a partir do Sul e com o Sul". Revista de Ciências Sociais. Fortaleza, v. 50, n. 2, jul./out.,2019, p. 15-30.

SILVA, Vagner Gonçalves da. Intolerância religiosa: impactos do neopentecostalismo no campo religioso afro-brasileiro. São Paulo: Edusp, 2007.

Recebido em: 04/10/2020

Aceito em: 16/12/2020 